\title{
CURRENT POSITION OF NATIONAL WEALTH ESTIMATION IN THE WORLD*
}

\author{
By L. Nesterov \\ United Nations Statistical Office
}

\begin{abstract}
A decade has passed since the last significant attempt to review methods of national wealth estimation of different countries in the world and available statistical data in this field. The results of this earlier review were discussed at the Fifth Conference of this Association in 1957 and published as Volume VIII of the Income and Wealth Series in 1959 [1]. For that conference Mr. Th. D. van der Weide of the Netherlands Central Bureau of Statistics prepared summary tables of available data (primarily the results of private estimators) on national wealth composition of 18 countries and on particular methods used. Those tables were the result of his timeconsuming recalculations on the basis of the international SNA classification. They provided some important facts to think over. First of all it was possible to discover many common features in the composition of the national wealth estimates which could serve as the basis of possible inter-country comparisons. Many estimators recognized only domestic reproducible tangible assets in the national wealth. Sub-soil deposits of minerals, standing timber and other natural resources were excluded from the estimates of most countries because of lack of reliable information and of difficulties in their evaluation, etc.

At the same time the conference showed clearly that inter-country comparisons involve numerous problems, even within an identical theoretical concept. The papers presented at that conference showed many differences in concepts of national wealth used, in actual coverage of those concepts with available data, in valuation methods, in price structure, etc. Some researchers stressed the need to put indicators of national wealth in a single and consistent framework of main economic indicators (national product, national income, fixed capital formation, etc.). It was evident also that national wealth estimating required solid background in statistical information for a long period of time and certain experience of that type of estimating, suitable for particular conditions and possibilities of the country. It is necessary to mention, nevertheless, that many questions of comparisons were not discussed, especially the questions of some particular problems of common monetary units for actual comparisons of national wealth estimates, and some other specific problems of comparability.

Since that conference there have been significant achievements in this field. The last decade evidenced numerous additions to the list of countries which have published estimates of national wealth (or its major components). Now there are more than 50 countries that have published such estimates, but only 15 countries succeeded in covering the whole range of national wealth components. Additional countries gathered information necessary for such estimates, but were unable to work out suitable ones. More than 40 countries (see Annex l) have official estimates made by their statistical administrations. Some countries have based their official estimates on special statistical surveys, inventories of their fixed and circulating assets as in the USSR, Czechoslovakia, Poland and Japan. Some countries are on the way to such special surveys (the U.S.A.). The OECD is working on such estimates but has not yet published them [2].

Sound results in each country may be obtained through hard and time-consuming work involving large amounts of calculations of reliable statistical information. For instance, preparation of recommendations to conduct an inventory in a large country such as the U.S.A. -The Wealth Inventory Planning Study-has required work of 150 experts in different fields [3]. About three million people participated in the USSR general inventory and revaluation of over 100 million objects of fixed assets in 1959 and 1961 [4]. Nevertheless, most countries have been satisfied with the work of a relatively small team of economists; in many cases their calculations had been simplified by the use of electronic computers. Electronic techniques have made it possible to process huge amounts of statistical information during all evaluations of wealth in the country.
\end{abstract}

*The views expressed in this paper are the sole responsibility of the author, and do not necessarily reflect the views of the Statistical Office. 
ANNEX I

Summary Characteristics of National Wealth Componentis Estimation in Different Countries of the World for the Post-war Period

\begin{tabular}{|c|c|c|c|c|c|c|c|c|c|c|}
\hline \multirow[b]{2}{*}{$\begin{array}{l}\text { Country or } \\
\text { Region }\end{array}$} & \multirow[b]{2}{*}{$\begin{array}{c}\text { Latest } \\
\text { Estimate } \\
\text { Available } \\
\end{array}$} & \multirow[b]{2}{*}{$\begin{array}{l}\text { Kind of } \\
\text { Estimate }\end{array}$} & \multicolumn{7}{|c|}{ Major Components of the Estimate } & \multirow[b]{2}{*}{ Coverage of the Estimate } \\
\hline & & & $\begin{array}{r}\text { Fixed } \\
\text { Assets } \\
\end{array}$ & Inventories & $\begin{array}{l}\text { Consumer } \\
\text { Durables }\end{array}$ & Land & $\begin{array}{c}\text { Other } \\
\text { Natural } \\
\text { Resources }\end{array}$ & $\begin{array}{c}\text { Net } \\
\text { Foreign } \\
\text { Assets } \\
\end{array}$ & $\begin{array}{c}\text { Non- } \\
\text { tangible } \\
\text { Assets }\end{array}$ & \\
\hline 1 & 2 & 3 & 4 & 5 & 6 & 7 & 8 & 9 & 10 & 11 \\
\hline \multicolumn{11}{|c|}{ I. Official estimates of statistical authorities } \\
\hline 1. Argentina & $\begin{array}{l}\text { End of 1946- } \\
1948\end{array}$ & $\begin{array}{l}\text { Census of book } \\
\text { values }\end{array}$ & $\times$ & $\times$ & - & $\times$ & - & - & - & $\begin{array}{l}\text { Industry, transport, state } \\
\text { property }\end{array}$ \\
\hline 2. Australia & $\begin{array}{l}\text { Middle of } \\
1966\end{array}$ & $\begin{array}{l}\text { Census of book } \\
\text { values }\end{array}$ & $x$ & $x$ & - & $x$ & - & - & 一 & $\begin{array}{l}\text { Mining, manufacturing, } \\
\text { communications, trade, } \\
\text { fishing }\end{array}$ \\
\hline 3. Brazil & End of 1959 & $\begin{array}{l}\text { Census of book } \\
\text { values }\end{array}$ & $x$ & - & - & - & - & - & 一 & Industry, commerce, services \\
\hline 4. Bulgaria & End of 1966 & $\begin{array}{l}\text { Annual balance } \\
\text { of re- } \\
\text { producible } \\
\text { value }\end{array}$ & $x$ & - & 一 & - & 一 & - & - & All economy \\
\hline \multirow[t]{2}{*}{ 5. Canada } & End of 1959 & $\left\{\begin{array}{l}\text { Perpetual } \\
\text { inventory }\end{array}\right.$ & $x$ & - & - & - & - & - & - & All economy \\
\hline & End of 1960$]$ & estimate & $x$ & - & 一 & - & - & - & 一 & Manufacturing \\
\hline 6. Czechoslovakia & End of 1966 & $\begin{array}{l}\text { Annual balance } \\
\text { of re- } \\
\text { producible } \\
\text { value }\end{array}$ & $x$ & 一 & 一 & - & - & 一 & - & All economy \\
\hline 7. Denmark & End of 1966 & $\begin{array}{l}\text { Annual assess- } \\
\text { ment of real } \\
\text { property }\end{array}$ & $x$ & - & + & $x$ & - & 一 & 一 & All economy \\
\hline 8. Ethiopia & Mid 1966 & $\begin{array}{l}\text { Annual survey } \\
\text { of book } \\
\text { value }\end{array}$ & $x$ & 一 & - & $x$ & - & - & - & Manufacturing, electricity \\
\hline $\begin{array}{l}\text { 9. Germany (Dem. } \\
\text { Rep.) }\end{array}$ & End of 1966 & $\begin{array}{l}\text { Annual balance } \\
\text { of re- } \\
\text { producible } \\
\text { value }\end{array}$ & $x$ & - & - & - & - & - & 一 & $\begin{array}{l}\text { Productive sphere of all } \\
\text { economy }\end{array}$ \\
\hline 10. Hungary & End of 1967 & $\begin{array}{l}\text { Annual balance } \\
\text { of re- } \\
\text { producible } \\
\text { value }\end{array}$ & $x$ & $x$ & $一$ & - & - & - & - & All economy \\
\hline
\end{tabular}




\begin{tabular}{|c|c|c|c|c|c|c|c|c|c|c|}
\hline 11. Iceland & End of 1964 & $\begin{array}{l}\text { Assessment of } \\
\text { real estate }\end{array}$ & $x$ & $x$ & - & $x$ & - & - & - & $\begin{array}{l}\text { Industry, agriculture, fishing, } \\
\text { housing }\end{array}$ \\
\hline 12. India & End of 1965 & $\begin{array}{l}\text { Annual survey } \\
\text { of book value }\end{array}$ & $x$ & $x$ & - & $x$ & - & $\infty$ & - & Industry \\
\hline 13. Iran & End of 1965 & $\begin{array}{l}\text { Annual survey } \\
\text { of book value }\end{array}$ & $x$ & $x$ & - & - & - & - & - & Manufacturing \\
\hline 14. Japan & End of 1955 ? & Sample survey & $x$ & $x$ & $x$ & - & - & $x$ & 一 & All economy \\
\hline & End of 1965 & $\begin{array}{l}\text { of reproducible } \\
\text { value }\end{array}$ & $x$ & $x$ & - & - & - & - & - & Business enterprises \\
\hline 15. Luxembourg & End of $1950^{\circ}$ & Mixed estimates & $x$ & $x$ & $x$ & $x$ & - & $x$ & $x$ & All economy \\
\hline 16. Libya & End of 1964 & $\begin{array}{l}\text { Survey of book } \\
\text { value }\end{array}$ & $x$ & - & - & - & $一$ & - & - & Large industrial units \\
\hline 17. Malawi & End of 1962 & $\begin{array}{l}\text { Survey of book } \\
\text { value }\end{array}$ & $x$ & $x$ & - & - & - & 一 & - & Industry \\
\hline 18. Mexico & End of 1965 & $\begin{array}{l}\text { Census of book } \\
\text { value }\end{array}$ & $x$ & $x$ & - & - & - & - & - & Industry and services \\
\hline 19. Nepal & End of 1965 & $\begin{array}{l}\text { Census of book } \\
\text { value }\end{array}$ & $x$ & - & - & $x$ & - & - & - & Industry \\
\hline 20. Netherlands & End of 1958 & Mixed estimates & $x$ & $x$ & - & $x$ & - & $x$ & - & All economy \\
\hline 21. New Zealand & Mid 1966 & $\begin{array}{l}\text { Survey of book } \\
\text { value }\end{array}$ & $x$ & $x$ & - & $x$ & - & $x$ & - & All economy \\
\hline 22. Norway & End of 1964 & Mixed estimates & $x$ & $x$ & $x$ & - & - & $x$ & - & All economy \\
\hline 23. Paraguay & End of 1963 & $\begin{array}{l}\text { Estimates of } \\
\text { market value }\end{array}$ & $x$ & $x$ & - & $x$ & - & - & - & Industry and electricity \\
\hline 24. Philippines & End of 1961 & $\begin{array}{l}\text { Census of book } \\
\text { value }\end{array}$ & $x$ & $x$ & - & - & - & - & - & All economy \\
\hline 25. Poland & End of 1965 & $\begin{array}{l}\text { Annual balance } \\
\text { of re- } \\
\text { producible } \\
\text { value }\end{array}$ & $x$ & 一 & - & - & - & - & - & All economy \\
\hline 26. Portugal & End of 1964 & $\begin{array}{l}\text { Census of book } \\
\text { value }\end{array}$ & $x$ & $x$ & - & $x$ & - & - & - & Industry \\
\hline 27. Pakistan & End of 1960 & $\begin{array}{l}\text { Census of book } \\
\text { value }\end{array}$ & $x$ & $x$ & - & $x$ & - & - & - & Industry \\
\hline $\begin{array}{l}\text { 28. Papua and } \\
\text { New Guinea }\end{array}$ & Mid 1967 & $\begin{array}{l}\text { Census of book } \\
\text { value }\end{array}$ & $x$ & - & 一 & $x$ & 一 & - & - & Industry \\
\hline 29. Rumania & End of 1966 & $\begin{array}{l}\text { Annual balance } \\
\text { of re- } \\
\text { producible } \\
\text { value }\end{array}$ & $x$ & - & - & - & - & - & - & All economy \\
\hline 30. Rhodesia, South & End of 1965 & $\begin{array}{l}\text { Survey of book } \\
\text { value }\end{array}$ & $x$ & $x$ & 一 & $x$ & 一 & 一 & 一 & Industry \\
\hline 31, Singapore & End of 1964 & $\begin{array}{l}\text { Survy of book } \\
\text { value }\end{array}$ & $x$ & $x$ & 一 & $x$ & 一 & - & - & Industry \\
\hline
\end{tabular}


ANNEX 1-continued

Summary Characteristics of National Wealth Components Estimation in Different Countries

OF THE WORLD FOR POST-WAR PERIOD-continued

\begin{tabular}{|c|c|c|c|c|c|c|c|c|c|c|}
\hline \multirow[b]{2}{*}{$\begin{array}{l}\text { Country or } \\
\text { Region }\end{array}$} & \multirow[b]{2}{*}{$\begin{array}{c}\text { Latest } \\
\text { Estimate } \\
\text { Available }\end{array}$} & \multirow[b]{2}{*}{$\begin{array}{l}\text { Kind of } \\
\text { Estimate }\end{array}$} & \multicolumn{7}{|c|}{ Major components of the estimate } & \multirow[b]{2}{*}{ Coverage of the Estimates } \\
\hline & & & $\begin{array}{l}\text { Fixed } \\
\text { Assets }\end{array}$ & Inventories & $\begin{array}{l}\text { Consumer } \\
\text { Durables }\end{array}$ & Land & $\begin{array}{c}\text { Other } \\
\text { Natural } \\
\text { Resources }\end{array}$ & $\begin{array}{c}\text { Net } \\
\text { Foreign } \\
\text { Assets }\end{array}$ & $\begin{array}{l}\text { Non- } \\
\text { tangible } \\
\text { Assets }\end{array}$ & \\
\hline 1 & 2 & 3 & 4 & 5 & 6 & 7 & 8 & 9 & 10 & 11 \\
\hline $\begin{array}{l}\text { 32. South African } \\
\text { Republic }\end{array}$ & End of 1962 & $\begin{array}{l}\text { Survey of book } \\
\text { value }\end{array}$ & $x$ & $x$ & - & $x$ & - & - & - & $\begin{array}{l}\text { Agriculture, industry, } \\
\text { construction, trade }\end{array}$ \\
\hline 33. Sweden & Mid 1967 & $\begin{array}{l}\text { Survey of } \\
\text { insurance } \\
\text { value }\end{array}$ & $x$ & - & - & - & - & - & - & Industry \\
\hline 34. Taiwan & End of 1961 & $\begin{array}{l}\text { Census of book } \\
\text { value }\end{array}$ & $x$ & 一 & - & $x$ & - & - & - & Industry, commerce, services \\
\hline 35. Thailand & End of 1963 & $\begin{array}{l}\text { Census of book } \\
\text { value }\end{array}$ & $x$ & $x$ & 一 & $x$ & - & - & - & Industry \\
\hline 36. Uruguay & End of 1960 & & $x$ & - & - & - & - & - & - & Industry \\
\hline 37. United Kingdom & End of 1967 & $\begin{array}{r}\text { Estimate of } \\
\text { perpetual } \\
\text { inventory }\end{array}$ & $x$ & $x$ & 一 & 一 & - & - & - & All economy \\
\hline 38. USA & End of 1966 & $\begin{array}{l}\text { Estimate of } \\
\text { perpetual } \\
\text { inventory }\end{array}$ & $x$ & - & - & - & - & 一 & - & Business assets \\
\hline 39. USSR & End of 1967 & $\begin{array}{l}\text { Annual balances } \\
\text { of reprodu- } \\
\text { cible value }\end{array}$ & $x$ & $x$ & - & - & - & - & - & All economy \\
\hline 40. Venezuela & End of 1965 & $\begin{array}{l}\text { Census and esti- } \\
\text { mates of per- } \\
\text { petual invent- } \\
\text { ory }\end{array}$ & $x$ & $x$ & 一 & - & - & 一 & - & All economy \\
\hline 41. Yugoslavia & End of 1966 & $\begin{array}{l}\text { Annual balances } \\
\text { of book values }\end{array}$ & $x$ & $x$ & - & 一 & - & - & - & Socialized sector of economy \\
\hline 42. Zambia & End of 1963 & $\begin{array}{l}\text { Survey of book } \\
\text { values }\end{array}$ & $x$ & $x$ & - & $x$ & - & - & - & Manufacturing \\
\hline 43. Costa-Rica & End of 1963 & $\begin{array}{l}\text { Survey of book } \\
\text { values }\end{array}$ & $x$ & $x$ & - & - & - & 一 & - & $\begin{array}{l}\text { Manufacturing, trade and } \\
\text { services }\end{array}$ \\
\hline \multicolumn{11}{|c|}{ II. Semi-official estimates (private estimates, reproduced in official publications) } \\
\hline 1. Sweden & End of 1952 & $\begin{array}{l}\text { Estimates of tax- } \\
\text { able property }\end{array}$ & $\times$ & $x$ & 一 & $x$ & $\times$ & $x$ & - & All economy \\
\hline 2. USA & End of 1966 & Mixed estimates & $\times$ & $\times$ & $\times$ & $\times$ & $x$ & $x$ & $x$ & All economy \\
\hline \multicolumn{11}{|c|}{ III. Private estimates of individual persons } \\
\hline 1. Argentina & End of 1955 & $\begin{array}{c}\text { Estimates of } \\
\text { perpetual } \\
\text { inventory }\end{array}$ & $x$ & - & - & - & - & - & - & All economy \\
\hline
\end{tabular}




\begin{tabular}{|c|c|c|c|c|c|c|c|c|c|c|}
\hline 2. Australia & Mid 1956 & $\begin{array}{l}\text { Estimates of } \\
\text { perpetual } \\
\text { inventory and } \\
\text { mixed } \\
\text { estimates }\end{array}$ & $x$ & $x$ & $x$ & $x$ & - & $x$ & $x$ & All economy \\
\hline 3. Belgium & End of 1960 & Mixed estimates & $x$ & $x$ & $x$ & $x$ & 一 & - & $x$ & All economy \\
\hline 4. Brazil & End of 1955 & Mixed estimates & $x$ & - & - & 一 & - & - & - & All economy \\
\hline 5. Canada & End of 1955 & Mixed estimates & $x$ & $x$ & $x$ & 一 & - & $x$ & - & All economy \\
\hline 6. Chile & End of 1955 & Mixed estimates & $x$ & - & - & - & - & - & - & All economy \\
\hline 7. Colombia & End of 1955 & Mixed estimates & $x$ & - & - & - & - & - & - & All economy \\
\hline 8. Finland & End of 1952 & No indication & $x$ & - & - & 一 & - & - & - & \\
\hline 9. France & End of 1960 & Mixed estimates & $x$ & $x$ & $x$ & $x$ & $x$ & 一 & $x$ & All economy \\
\hline $\begin{array}{l}\text { 10. Germany (Fed. } \\
\text { Rep.) }\end{array}$ & End of 1960 & Mixed estimates & $x$ & $x$ & $x$ & $x$ & - & - & $x$ & All economy \\
\hline 11. Greece & End of 1960 & Mixed estimates & $x$ & 一 & 一 & - & - & - & - & Manufacturing \\
\hline 12. Honduras & End of 1955 & $\begin{array}{l}\text { Perpetual in- } \\
\text { ventory and } \\
\text { mixed } \\
\text { estimates }\end{array}$ & $x$ & $x$ & $x$ & $x$ & $x$ & $x$ & - & All economy \\
\hline 13. India & Mid 1950 & $\begin{array}{l}\text { Perpetual in- } \\
\text { ventory and } \\
\text { mixed estimates }\end{array}$ & $x$ & $x$ & $x$ & $x$ & $x$ & - & - & All economy \\
\hline 14. Israel & End of 1962 & No indication & $x$ & $x$ & $x$ & $x$ & $x$ & $x$ & $x$ & All economy \\
\hline 15. Italy & End of 1961 & Mixed estimates & $x$ & $x$ & $x$ & $x$ & $x$ & - & $x$ & All economy \\
\hline 16. Mexico & End of 1960 & Mixed estimates & $x$ & $x$ & $x$ & $x$ & $x$ & $x$ & $x$ & All economy \\
\hline $\begin{array}{l}\text { 17. South African } \\
\text { Republic }\end{array}$ & End of 1955 & $\begin{array}{l}\text { Estimate of } \\
\text { perpetual } \\
\text { inventory }\end{array}$ & $x$ & $x$ & $x$ & $x$ & - & $x$ & - & All economy \\
\hline 18. Spain & & Mixed estimates & $\dddot{x}$ & $\dddot{x}$ & $\ddot{x}$ & $\ddot{x}$ & $\ddot{x}$ & $\ddot{x}$ & $\ddot{x}$ & All $\cdots$ \\
\hline $\begin{array}{l}\text { 19. USA } \\
\text { 20. USSR }\end{array}$ & $\begin{array}{l}\text { End of } 1966 \\
\text { End of } 1962\end{array}$ & $\begin{array}{l}\text { Mixed estimates } \\
\text { Annual balances }\end{array}$ & $x$ & $x$ & $x$ & $\underline{2}$ & $\underline{x}$ & $\underline{-}$ & $\underline{x}$ & All economy \\
\hline 20. USSK & & $\begin{array}{l}\text { Annual balances } \\
\text { of reproducible } \\
\text { value }\end{array}$ & & & & & & & - & All economy \\
\hline 21. Venezuela & End of 1954 & $\begin{array}{l}\text { Estimate of } \\
\text { perpetual } \\
\text { inventory }\end{array}$ & $x$ & 一 & 一 & - & - & - & 一 & All economy \\
\hline 22. Yugoslavia & End of 1960 & $\begin{array}{l}\text { Perpetual inven- } \\
\text { tory and mixed } \\
\text { estimates }\end{array}$ & $x$ & $x$ & $x$ & - & - & 一 & - & All economy \\
\hline & \multicolumn{10}{|c|}{ IV. Regional and world estimates } \\
\hline 1. Latin America & End of 1954 & $\begin{array}{l}\text { Perpetual } \\
\text { inventory }\end{array}$ & $x$ & - & - & - & 一 & - & - & All economy \\
\hline 2. World & End of 1952 & $\begin{array}{l}\text { Perpetual } \\
\text { inventory }\end{array}$ & $x$ & $x$ & $x$ & $x$ & $x$ & $x$ & $x$ & All economy \\
\hline
\end{tabular}


It is worth noting that adoption of the United Nations System of National Accounts (SNA) by most countries with market economies in the post-war period is a good basefor improvement of many estimates including national wealth. First of all, the SNA provides mutual reconciliation of all national aggregates within a framework balancing the flows of all resources and expenses in the country for certain periods of time. This is an important factor for significant improvement of the accuracy of estimation, especially in capital formation indicators, with the help of which it is possible to calculate annual changes in the stock of main national wealth assets. Besides that, a high degree of accuracy in the total volume of capital formation makes it possible to reconcile the detailed data on particular processes of capital formation in every sector of the economy, in each asset of it. The last indicators are widely used in many countries for calculating the stock of fixed and circulating assets at a given date. One of the most vivid examples was given by the Norwegian Central Statistical Bureau which in 1965 published its estimates of national real capital for nearly a whole century, for 1865-1960. Its main economic indicators are mutually consistent and provide a solid base for much sound economic analysis. It is interesting to mention also that in 1953 the U.N. Statistical Office issued a report on an international standard, A System of National Accounts and Supporting Tables [5], which was three times revised (in 1958, 1964 and 1968). This international recommendation has helped many countries to organize their own systems of main economic indicators. In the first postwar years such systems were applied in only a few West-European countries, but now such systems have been applied in a hundred countries. In 1958 the U.N. Statistical Office inaugurated the first issue of the Yearbook of National Accounts Statistics [8] with information on 70 countries and territories. The latest available (eleventh) issue for 1967 provides information on 112 countries and territories. In the first issue of this Yearbook, 56 countries provided estimates of fixed capital formation (usually of a single aggregate without details of its structure). The last issue of this Yearbook contains detailed information on composition of fixed capital formation for 86 countries and on total volume for 105 countries. So, this Yearbook has helped to gather very valuable and rather detailed information on fixed capital formation for the period since 1950 for most countries of the world within the framework of SNA.

All available national experience and new trends in estimation techniques should be summarized, analysed and discussed thoroughly to choose the most interesting and effective methods. Such examples will be of great help to those countries which have not yet started evaluation of their wealth. They will be in a position to decide which of the methods is the most suitable for their own particular conditions. At the same time, such a review will be of great help to draft sound international recommendations as a standard for inter-country comparisons. This is a task not for individual researchers (which was a characteristic in the past) but for international organisations.

In October 1966 the fourteenth session of the U.N. Statistical Commission adopted the Integrated five-year programme of international statistics [7]. The programme proposes to ". . develop international suggestions in respect of the compilation and collection of statistics of real wealth; and prepare a study, including national practices, problems and developments, on the needs for objectives of these data, concepts, methods of valuation, classifications and tabulations of wealth statistics, and sources and methods of collecting and estimating the data" [7].

In line with this programme, a review was made. The review covered published information to obtain an idea of how many countries had any experience in the field of national wealth estimation during the post-war period and what were the main features of those estimates. Annex $I$ to this paper is a result of some systematization of the available information on more than 50 countries. It is quite possible that not all estimates (especially private) were covered in this review because its main focus was on official statistical publications.

All information gathered may be considered from several points of view according to the significance of the published estimates, to their scope, to methods of estimation, to kind of stock estimates, etc.

The published estimates may be classified geographically as follows: 


\begin{tabular}{|c|c|c|c|c|}
\hline Europe & America & Asia & Africa & Oceania \\
\hline $\begin{array}{l}\text { 1. Belgium* } \\
\text { 2. Bulgaria } \\
\text { 3. Czechoslovakia } \\
\text { 4. Denmark } \\
\text { 5. Finland } \\
\text { 6. France* } \\
\text { 7. Germany, D. R. } \\
\text { 8. Germany, F. R.* } \\
\text { 9. Greece } \\
\text { 10. Hungary } \\
\text { 11. Iceland } \\
\text { 12. Italy* } \\
\text { 13. Luxembourg* } \\
\text { 14. Netherlands } \\
\text { 15. Norway* } \\
\text { 16. Poland } \\
\text { 17. Rumania } \\
\text { 18. Spain } \\
\text { 19. Sweden* } \\
\text { 20. UK } \\
\text { 21. USSR* } \\
\text { 22. Yugoslavia* }\end{array}$ & $\begin{array}{l}\text { 1. Argentina } \\
\text { 2. Brazil } \\
\text { 3. Canada* } \\
\text { 4. Chile } \\
\text { 5. Colombia } \\
\text { 6. Honduras* } \\
\text { 7. Mexico } \\
\text { 8. Paraguay } \\
\text { 9. Uruguay } \\
\text { 10. USA* } \\
\text { 11. Venezuela } \\
\text { 12. Costa-Rica }\end{array}$ & $\begin{array}{l}\text { 1. India* } \\
\text { 2. Iran } \\
\text { 3. Israel* } \\
\text { 4. Japan* } \\
\text { 5. Nepal } \\
\text { 6. Philippines } \\
\text { 7. Pakistan } \\
\text { 8. Singapore } \\
\text { 9. Taiwan } \\
\text { 10. Thailand }\end{array}$ & $\begin{array}{l}\text { 1. Ethiopia } \\
\text { 2. Libya } \\
\text { 3. Malawi } \\
\text { 4. Rhodesia, South } \\
\text { 5. South Africa* } \\
\text { 6. Zambia }\end{array}$ & $\begin{array}{l}\text { 1. Australia* } \\
\text { 2. New Zealand } \\
\text { 3. Papua and } \\
\text { New Guinea }\end{array}$ \\
\hline
\end{tabular}

Published estimates cover at least the following major elements of national wealth: Fixed assets Circulating assets (inventories)

Consumer durables (except for Sweden)

Net foreign assets (except for Germany, India and USSR)

Land (in many cases).

So, out of 53 countries that have published estimates on major elements of national wealth, 22 countries are in Europe, 12 in America, 10 in Asia, 6 in Africa and 3 in Oceania. But only in 18 cases do the estimates cover at least reproducible tangible assets and net foreign assets, or only in those countries may the estimates be considered practically as national wealth ( 9 in Europe, 3 in America, 3 in Asia, 1 in Africa and 1 in Oceania).

According to the significance of the published estimates they may be classified into three groups:

1. The first group of estimates of national statistical administrations (they may be titled also as Bureaus or as Offices) is the largest and consists of 43 countries, and among them it is possible to mention countries with the centrally planned economies (the USSR, Czechoslovakia, Poland and others) as well as the USA, UK, Japan and others.

2. The second group embraces two countries-Sweden and the USA-as having semiofficial estimates (i.e. private estimates reproduced in official statistical publications with reference to their authors).

3. The third group consists of private estimates. Many of them covered the bulk of elements comprising national wealth for several Latin-American countries (Argentina, Brazil, Chile, Colombia, Mexico and Venezuela), and for the region as a whole estimates were prepared under the auspices of the U.N. Economic Commission for Latin America. In this group, it is possible to find an attempt to evaluate national wealth of the world as a whole. Some countries may be found in two groups (Australia, Canada, Japan, UK, USSR, Yugoslavia and others) and even in three groups (USA).

The first main conclusion that can be reached from the material gathered is that the time has arrived to spread the rich experience of some countries in national wealth estimation. The U.N. Statistical Office now is accumulating published information on national experience of statistical administrations and private researchers to draft possible recommendations. At the same time it will be extremely useful if the IARIW tries once more to summarize new experience of individual researchers in different countries of the world and to prepare a new study in this field, sponsoring also national wealth estimation in many new countries of the world. 
According to the methods of estimation all published material may be classified as follows:

(a) general inventory (and revaluation) or census,

(b) inventory with samples of detailed characteristics,

(c) survey of book values for fixed and circulating assets (in some cases with revaluation of assets),

(d) "perpetual inventory",

(e) capitalisation (Giffen) method,

(f) real property assessment.

(g) mixed methods,

Surveys of bookkeeping records on fixed and circulating assets usually are the first steps in gathering information on major national wealth components. This method is characteristic not only for numerous recent newcomers in national wealth statistics but also for Australia where the statistical services have used this method since the beginning of this century. But without the subsequent revaluation of such data into the prices of a given base year this information has little significance for economic analysis. Several countries are in favor of the perpetual inventory method which can be successfully used in estimation on the basis of available detailed information on capital formation in the country for a long period of time. Centrally planned economies use annual balances of fixed and circulating assets in the whole economy (both book values and revaluated estimates) as the chief method for national wealth estimation supplemented by calculations based on information from family budget surveys, etc. But the experience of all experienced countries showed the necessity for solid detailed benchmarks-information from censuses, surveys or special statistical observations on national wealth main components.

Certain peculiarities may be found in each country implementing those methods, but general principles are very close. So it will be possible to formulate the second main conclusion that there is a good base for an international recommendation for the countries to choose the methods most suitable for the particular conditions.

The same conclusion may be reached on concepts, on scope and other aspects of national wealth estimation.

The time is ripe to start this work on a new level of international organisations and through cooperation of all statistical organisations and individual researchers who are eager to provide valuable information for analysis of economic growth of countries and the world.

\section{Some References:}

1. Income and Wealth, Series VIII, London, 1959.

2. The Review of Income and Wealth, 1966, No. 2, pp. 128-129.

3. Measuring the Nation's Wealth, United States Government Printing Office, Washington, 1954, p. XII.

4. Planovoe khoziaistwo (Planned Economy) 1960, No. 10, p. 7; 1962, No. 11, p. 48.

5. A System of National Accounts and Supporting Tables, Studies in Methods, Series F, No. 2, Rev. 2, United Nations, New York, 1964.

6. Statistical Commission, Report of the Fourteenth Session, United Nations, New York, E/CN.3/354, pp. 6-7.

7. Integrated Five-Year Programme of International Statistics. United Nations, New York, E/CN.3/351, p. 74.

8. Yearbook of National Accounts Statistics, United Nations, New York, N.Y., 1958 and 1968. 


\section{ANNEX II \\ List of Main Publications \\ Containing Country Estimates of National Wealth}

\section{Estimates Published by Regional or Interregional Organizations}

1. The United Nations Economic Commission for Latin America (ECLA) in (a) Economic Survey of Latin America 1951-1952, N.Y. 1954 (E/CN.12/291/Rev.2)-estimates for Argentina, Brazil, Chile, Mexico and for the whole region; in (b) Economic Survey of Latin America, 1954, N.Y. 1955 (E/CN.12/362/Rev.1)--estimates for Venezuela, Argentina, Chile and for the whole region.

2. EEC, Office Statistique des Communautés Européenes in Informations Statistiques (Série orange) 1960, No. 6, estimates for Australia, Belgium, Canada, Finland, France, Germany (F.R.), Italy, Netherlands, Norway, Sweden, U.S.A., United Kingdom.

3. IARIW, Income and Wealth, Series VII. (London, 1959), estimates for Belgium, Luxembourg, Netherlands, Germany (F.R.), France, United Kingdom, Sweden, Norway, Yugoslavia, Canada, U.S.A., Mexico, Australia, South Africa, Argentina, Colombia, Japan, India.

4. IARIW, The Review of Income and Wealth, Series 12, No. 2 (June 1966), pp. 128-130; estimates for U.S.A., U.K., France, Germany (F.R.), Belgium, Norway, Italy, Japan, Israel, Mexico, India and U.S.S.R.

\section{Country Estimates}

1. Argentina

(a) Direccion General del Servicio Estadistico Nacional in IV Censo General de la Nacion, Censo Industrial de 1946, Buenos Aires, 1949, p. 63.

(b) ECLA in I. 1(a), pp. 36-50.

(c) M. Balboa, A. Fracchia and A. Ganz in I.3., pp. 242-251; 274-292.

2. Australia (a) Commonwealth Bureau of Census and Statistics (CBCS)-in Yearbook of Common-
wealth of Australia, No. 53 for 1967 (and in previous issues); in A Summary of Principal Statistics of Factories, No. 19 (1966-1967), Canberra 1967, pp. 7, 32, 33 (and previous issues); in Manufacturing Industry, Bull. No. 2 (1964-1965), Canberra, 1967, pp. 1, 71-81 and previous issues.
(b) T. M. Garland and R. W. Goldsmith in I.3., pp. 323-364.
(c) EEC in I.2.
3. Belgium
(a) G. Labeau in Cashiers économiques de Bruxelles, No. 25 (1965), pp. 5-46.
(b) C. Duprez and B. Kahn, reproduced in I.2. (pp. 588-589).
(c) F.Baudhuin, reproduced in I.3. (pp. 8-33).
(d) OECD, reproduced in $\mathbf{1 . 4}$.

4. Brazil
(a) Servico Nacional de Recenseamento in VII Recenseamento Geral do Brasil, Vol. III Censo Industrial de 1960, pp. 61, 115; Vol. IV Censo Comercial e dos Serviços de 1960, pp. 10, 11, 46-51, 114-115, 160-171.
(b) ECLA by A. Ganz in 1.1(a), pp. 51-62.

5. Bulgaria

(a) Central Statistical Administration in Statistical Yearbook (Статистически годишник на НРБ) for 1966 (as well as for previous years), pp. 87-90, 102-104; 129-169; 212-214; $220-222 ; 225-246 ; 394 ; 449-460$.

6. Canada
(a) Dominion Bureau of Statistics in
-Daily Bulletin, Supplement-2; Dec. 22, 1965.
-Fixed Capital Flows and Stocks Manufacturing, Canada 1926-1960, Ottawa 1967.
- Canada Year Book, 1966 (and in previous issues), pp. 514, 716, 765, 782-784; 805, 833,880 . 
(b) O. J. Firestone in Income and Wealth, Series VII, (1958),

(c) W. M. Hood and A. Scott in Output, Labour and Capital in the Canadian Economy, Ottawa, 1957 (especially pp. 227-306, 401-492).

(d) A. Scott in I.3., pp. 193-216.

(e) G. W. Wilson, S. Gordon and S. Judek in Canada: an appraisal of its needs and resources, N.Y. 1965 (especially Part II).

7. Chile

(a) ECLA by A. Ganz in I.1(a), pp. 62-75.

(b) ECLA in I.1(b), p. 24.

8. Colombia

(a) ECLA by A. Ganz in I.3., pp. 225, 229; 251-260.

8. Costa Rica

Direccion General de Estadistica y Censos, in III Censo de Industrias Manufactueras 1964, pp. 75-79; 83-93; in III Censo de Comercio y Servicios 1964, pp. 33-49; 63-65.

9. Czechoslovakia

(a) Central Statistical Administration in Statistical Yearbook (Statisticka Rochenka CSSR) for 1967 (and in previous issues), pp. 153-156; 179-187.

10. Denmark

Statistical Bureau of Denmark in Statistical Yearbook (Statistisk Ärbog, 1968), pp. 83-87.

11. Ethiopia

Central Statistical Office in Statistical Abstract, 1966, pp. 59, 62.

12. Finland

(a) L. Tornquist in Statistiska Institutionen Helsingfors Universitet Särtryck, Series No. I Helsinki, 1958.

(b) EEC in I.2.

13. France

(a) EEC in I.2.

(b) OECD, reproduced in $I .4$.

14. Germany (D.R.)

Central Statistical Office in Statistical Yearbook (Statistisches Jahrbuch, 1968, der DDR), Berlin 1968, p. 55.

15. Germany (F.R.)

(a) Deutsches Institute für Wirtschaftsforschung in Sonderheftes, Reihe A No. 34, 41, $42,62$.

(b) IARIW in I.3., pp. 147-159.

(c) IARIW in I.4.

16. Greece

(a) Center of Planning and Economic Research in Research Monograph Series, No. 16 (Athens, 1966) (Fixed Capital Stock and Future Investment Requirements in Greek Manufacturing by R. Krengel and D. Mertens).

17. Honduras

Central Bank of Honduras, by E. Tosco in Riqueza Nacional de Honduras, C.A.-1955, Tegucigalpa, Sept. 1957, mimeographed.

18. Hungary

(a) Central Statistical Office-in Statistical Yearbook 1966 (Statisztikai Ecönyv), Budapest 1967, p. 41; in A Népgazdaság Allóeszközei, 1959-1961, Budapest 1963; in Statisztikai Idögzaki Kèzlemènyek; 94 kötet, Budapest 1965, pp. 45-46; 103 kötet, Budapest 1967, pp. 16-17, 21-53.

19. Iceland

Statistical Bureau in Statistical Abstract (Tölfrdedihandbók), Reykjavik 1967, pp. 88-89, in Hagskyrslur Islands, Series II, No. 29 (Industrial Production Statistics for 1960), pp. 28-31, 38-39; No. 38 (Fishery Industry), pp. 1, 15.

20. India

(a) Department of Statistics-in Annual Survey of Industries, 1965, Calcutta 1967; and in previous issues since 1958; up to 1958 there were 13 Censuses of Indian Manufacturers (Annual).

(b) IARIW in I.3., pp. 365-389. 
(c) IARIW in I.4.

(d) M. S. Joshi, The National Balance Sheet of India, University of Bombay, Bombay 1966, esp. p. 10.

21. Iran

Bureau of Statistics, Ministry of Economy in Report on the Results of Annual Industrial Survey in 1965, Teheran 1967, pp. II, VIII, XVI.

22. Israel

By R. Goldsmith in I.4.

23. Italy

(a) Banca Nazionale del Lavoro by A. Giannone in Quarterly Review, Dec. 1963, pp. 421436.

(b) EEC in I.2., pp. 588, 655, 665

(c) IARIW in I.4.

(d) G. Corrado in L'Ammontare e la Composizione della Ricchezza delle Nazioni, Torino 1962.

24. Japan

(a) Bureau of Statistics of the Prime Minister in Japan Statistical Yearbook ... for 1963, pp. $406-407$; . . f for 1965 , pp. $456-457$.

(b) Economic Research Institute, Economic Planning Agency, Japanese Government in Economic Bulletin No. 1 (National Income Accounts, 1957 and National Wealth Survey, 1955).

(c) The Bank of Japan in Hundred-Year Statistics of the Japanese Economy, Tokyo 1966, pp. 20-27.

(d) K. Ohkawa, in The Growth Rate of the Japanese Economy since 1878, Tokyo 1957, in Capital Stock, Tokyo 1966.

25. Libya

Ministry of Economy and Trade, Census and Statistical Department in Statistical Abstract 1966, Tripoli 1966, p. 76.

26. Luxembourg

(a) Ministry of Economics in Documentation Economique, Cahiers économiques du service d'études no. 1 (La Fortune Nationale du Grande-Duché de Luxembourg en 1950).

27. Malawi

National Statistical Office in 1962 Census of Industrial Production, Zomba 1965, pp. 9, $15,20$.

28. Mexico

(a) Central Statistical Office in V Censo de Servicios 1966, Mexico 1967, Resumen General, p. 3; in VIII Censo Industrial 1966, Mexico 1967, Resumen General, p. 3; in V Censo Commercial, 1966, Resumen General, pp. 3-20.

(b) ECLA in I.1(a), pp. 75-89.

(c) IARIW in I.3., pp. 225-230, in I.4.

29. Nepal

Central Bureau of Statistics in Preliminary Results of the Census of Manufacturing Establishments 1965, Kamalpokhari, Kathmandu, 1967, pp. 14, 50-55.

30. Netherlands

Central Bureau of Statistics in Statistische en Econometrische Onderzoekingen (quarterly publication) 1947, No. 3, p. 66;1954, No. 1, p. 3; in National Accounts of the Netherlands, 1948-1949 (Part I-The National Wealth of the Netherlands, Den Haage 1952); in Statistical Studies, No. 3, Den Haage 1954.

31. New Zealaind

Department of Statistics in New Zealand Official Yearbook 1968, Wellington 1968, pp. 203-207; 501-503; 582-601, 1 053; in Statistics of Industrial Production for Production Year 1965-1966, Wellington 1968, Tables 1, 3, 43, 44, 45.

32. Norway

(a) Central Bureau of Statistics in Norges Officielle Statistikk VII. 163 (Oslo, 1965National Accounts for 1865-1960).

(b) IARIW in I.3., pp. 80-118.

(c) IARIW in I.4.

33. Pakistan

Central Statistical Office in Statistical Yearbook 1964, Karachi 1966, pp. 140-143. 
34. Papua and New Guinea

Bureau of Statistics, Konedobu, in Quarterly Summary of Statistics, No. 35, March 1965,

p. 8; in Secondary Industries, Bulletin No. 9 (1966-1967), pp. 3, 24-26 (and in previous issues).

35. Paraguay

Ministerio de Industria y Comercio in Censos Economicos 1963, Asunción 1966, pp. 56-58.

36. Philippines

Bureau of the Census and Statistics in Economic Census of the Philippines 1961, Manila

1965, Vols. I-VIII; in Annual Survey of Manufactures 1965, Manilla 1968, pp. 34-41.

37. Poland

Central Statistical Office in Statistical Yearbook (Rocznik Statistiyczny) 1967, pp. 112-116.

38. Portugal

Instituto Nacional de Estatistica in Inquérito Industrial 1964, Lisbon 1968, Tomo I, pp. 5-7, 14-21.

39. Rhodesia, Southern

Central Statistical Office in The Census of Production in 1965, Salisbury 1967, pp. 46-60.

40. Romania

Central Statistical Office in Statistical Yearbook (Annuarul Statistic a 1 RSR) for 1967, Bucuresti 1967, pp. 112-113; in Statistical Pocket Book of the Socialist Republic of Romania 1968, pp. 41-44.

41. Singapore

Department of Statistics in Report on the Census of Industrial Production 1965, Singapore 1966, pp. 7, 23-30.

42. South Africa

(a) Bureau of Statistics in Statistical Yearbook 1966, Pretoria 1966, pp. J-22; M-8; M-14, $15 ; \mathrm{N}-4,5 ; \mathrm{O}-3 ; \mathrm{P}-2,3$.

(b) IARIW by D. G. Franzsen and J. J. D. Willers in I.3.; pp. 292-322.

43. Sweden

Central Statistical Bureau in Industri 1966 (Annual Survey of Industrial Activity; Information on Fixed Assets Gathered since 1964), Stockholm 1967, pp. 12-14, 422-428; in Statistik Tidskrift (monthly) 1956, No. 10, pp. 493-518.

44. Taiwan

Ministry of Industry and Commerce in General Report 1961 Industry and Commerce Census of Taiwan, Taipei 1962, pp. 152-164; 176-187.

45. Thailand

National Statistical Office in Report on the 1964 Industrial Census, Bangkok 1967, pp. 2-5; 8-16; 55-59.

46. United Kingdom

(a) Central Statistical Office in annual National Income and Expenditure, 1968, pp. 79-87 (and in previous issues).

(b) T. Barna in the Journal of the Royal Statistical Society (J.R.S.S.), Series A, Vol. 120, pt.I. (1957), pp. 1-46; in I.3., pp. 35-59.

(c) P. Redfern in J.R.S.S. Series A, Vol, 118, pt. 2, pp. 141-192.

(d) G. Dean in J.R.S.S. Series A, Vol. 127, pt. 3 (1964), pp. 327-351.

(e) C. H. Feinstein in Domestic Capital Formation in the United Kingdom 1920-1938, Cambridge 1965.

(f) IARIW in I.4.

47. United States

(a) Department of Commerce in Historical Statistics of the United States, Colonial Times to 1957, Washington 1960, pp. 145-158; in Statistical Abstract of the United States for 1968, pp. 336-337 (and in previous issues); in Survey of Current Business: Nov. 1956; Dec. 1966; Feb. 1967; Feb. 1969.

(b) Joint Economic Committee; Congress of the United States in Measuring the Nation's Wealth, Dec. 1964.

(c) Conference on Research in Income and Wealth in Studies in Income and Wealth, Vols. No. II-XII; XIX.

(d) R. W. Goldsmith in A Study of Saving in the United States, Princeton 1955-1956, especially Vol. III; in The National Wealth of the United States in the Postwar Period, Princeton 1962; in I.4.

(e) Finance Magazine 1967, Nos. 1, 2. 
48. Uruguay

(a) Dirección General de Estadistíca y Censos in Anuario Estadistíco 1955-1960, Montevideo 1963, p. J-2.

(b) Asociación de Bancos del Uruguay in Resumen de los Principales Aspectos de la Actividad Economica del Uruguay en el Año 1962, Montevideo 1963, Cuardo estadistico Nos. 41, $43,60,61$.

49. $U S S R$

(a) Central Statistical Administration of the USSR in Statistical Yearbook (Hapotдное хозяйство СССР) for 1959 , pp. 62-75; for 1965 , pp. 55-65; 812-814; 817-818; 829-830; in Statistical monthly (Вестник статистики) for 1960, No. 10, pp. 3-11; in National Economy of the USSR, Moscow 1957, pp. 26-30.

(b) State Planning Committee in Monthly (Плановое хозяйство) 1960, No. 10, pp. 3$12 ; 1962$, No. 11, pp. 48-53.

(c) B. H. Kirichenko in National Wealth of the USSR (Narodnoe bogatstvo SSSR) Moscow 1964, esp. pp. 68-77, 181.

(d) IARIW by Alb. L. Vainshstein The Problems of International Statistical Comparisons of National Wealth (with reference to comparison of the USSR and the USA)paper presented at VIII general conference (mimeographed).

50. Venezuela
(a) Dirección General de Estadística y Censos Nacionales in Statistical Yearbook Compendio Estadistico de Venezuela, Caracas 1968, pp. 357-378.
(b) ECLA by B. Ferran in I.1(b), pp. 4-5.

51. Yugoslavia

(a) Federal Institute for Statistics in Statistical Yearbook (Statisticki Gbdisnjak, Beograd 1968, pp. 126-129 (and in previous issues); in Statistical Bulletin Statisticki Bilten, No. 351 (maj 1965).

(b) I. Vinski in Procjena Nacionalnog Bogatstva po Podrucjima jugoslavije, Zagred 1959; in Ekonomist, Beograd, Vol. 18, No. 4(1965), pp. 667-679; in Regional Science Association Papers, Vol. VIII, pp. 127-168; Vol. XII, pp. 127-151; in I.3., pp. 160-192.

52. Zambia

Central Statistical Office in Census of Production 1964, Lusaka 1966, pp. 6, 62, 9-15.

III. WORLD ESTIMATES

1. R. R. Doane in "World Balance Sheet", Harper and Brothers, New York, 1952, esp. pp. 210-211. 